\title{
GROWTH AND SEED YIELD OF SUNFLOWER ON SOIL FERTILIZED WITH CASSAVA WASTEWATER ${ }^{1}$
}

\author{
MARA SUYANE MARQUES DANTAS ${ }^{2}$, MARIO MONTEIRO ROLIM ${ }^{2} *$ ELVIRA MARIA REGIS PEDROSA ${ }^{2}$, \\ MANASSÉS MESQUITA DA SILVA², DANIEL DA COSTA DANTAS ${ }^{2}$
}

\begin{abstract}
Cassava wastewater is the liquid residue of the cassava flour processing and its application to the soil as fertilizer for agricultural crops is a good alternative to sources of nutrients for plants. In this context, the objective of this work was to evaluate the growth and seed yield of sunflower on soil fertilized with cassava wastewater. A randomized block experimental design with four replications was used, with six cassava wastewater rates $\left(0,8.5,17,34,68\right.$ and $\left.136 \mathrm{~m}^{3} \mathrm{ha}^{-1}\right)$ and six plant sampling times $(15,30,45,60,75$ and 90 days after sowing), using the sunflower cultivar Helio-250. The evaluated variables were total leaf area, leaf area index, leaf area ratio, specific leaf area, leaf weight ratio, shoot dry mass and sunflower seed yield. The use of cassava wastewater rate of $136 \mathrm{~m}^{3} \mathrm{ha}^{-1}$ increases the seed yield, leaf area, leaf area index and shoot dry mass, and results in lower leaf area ratio, specific leaf area and leaf weight ratio of sunflower (cv. Helio-250) crops.
\end{abstract}

Key words: Helianthus annuus. Manihot esculenta. Liquid residue. Physiological índices.

\section{ANÁLISE DE CRESCIMENTO E PRODUTIVIDADE DO GIRASSOL ADUBADO COM ÁGUA RESIDUÁRIA DA MANDIOCA}

RESUMO - A aplicação da manipueira, resíduo liquido do processamento da mandioca, em cultivos agrícolas apresenta-se como uma boa alternativa como fonte de nutrientes para as plantas. Nesta perspectiva o objetivo desta pesquisa foi analisar o crescimento e a produtividade de plantas de girassol adubadas com manipueira. $\mathrm{O}$ delineamento experimental utilizado foi em blocos ao acaso, com seis doses de manipueira $(0 ; 8,5 ; 17 ; 34 ; 68$ e $\left.136 \mathrm{~m}^{3} \mathrm{ha}^{-1}\right)$ em quatro repetições, sendo avaliados em seis épocas de amostragens das plantas $(15,30,45,60$, 75 e 90 dias após a semeadura - DAS), utilizando-se a cultivar de girassol, Helio 250. As variáveis avaliadas foram a área foliar, o índice de área foliar, a razão de área foliar, a área foliar específica, a razão de peso foliar, a massa seca da parte aérea das plantas e a produtividade. A dose de manipueira igual a $136 \mathrm{~m}^{3} \mathrm{ha}^{-1}$ propiciou maiores produtividade, área foliar, índice de área foliar e massa seca da parte aérea. Os menores valores de razão de área foliar, área foliar específica e a razão de peso foliar foram obtidos quando se utilizou a dose de $136 \mathrm{~m}^{3} \mathrm{ha}^{-1}$.

Palavras-chave: Helianthus annuus. Manihot esculenta. Resíduo líquido. Índices fisiológicos.

\footnotetext{
${ }^{*}$ Corresponding author

${ }^{1}$ Received for publication in $04 / 04 / 2016$; accepted in $01 / 26 / 2017$.

Paper extracted from the doctoral thesis of the first author.

${ }^{2}$ Department of Agricultural Engineering, Universidade Federal Rural de Pernambuco, Recife, PE, Brazil; marasuyane@hotmail.com, mario.rolim@ufrpe.br, elvira.pedrosa@ufrpe.br, manasses.mesquita@ufrpe.br,d1cdantas@hotmail.com.
} 


\section{INTRODUCTION}

Advances in agricultural production systems in recent decades have increased the consumption of inputs and generation of waste by agricultural and agro-industrial activities, aggravating global environmental problems such as the destruction of the ozone layer, greenhouse effect and loss of biodiversity; and local problems caused by the impacts of the generation of liquid and solid waste.

The processing for cassava flour production generates solid and liquid residues, from which the cassava wastewater is the most harmful to the environment, due to its high content of organic compounds and of linamarin, which is a cyanogenic glycoside of high toxicity (CAMPOS et al., 2006). However, the nutrient contents of cassava wastewater, especially potassium, magnesium, nitrogen and phosphorus, can be used as soil bio-fertilizer for agricultural activities (CARDOSO et al., 2009).

Adding value to agricultural and agro-industrial waste can contributes to a more sustainable economic and social development. Therefore, the use of cassava wastewater in agriculture can be a viable alternative to source nutrients for plants and reduce environmental impacts, contributing to a low-carbon emission agriculture (DANTAS et al., 2015).

Sunflower (Helianthus annuus L.) stands out as one of the four main annual oil producing crops of the world. This oleaginous plant presents important characteristics, such as resistance to drought, cold and heat, adapts to different soil and climate conditions, and can be grown all year round. Besides, sunflower is an important crop for the world economy, since the sunflower seed production is approximately 45 million $\mathrm{Mg} \mathrm{yr}^{-1}$. The planted area of sunflower in Brazil, in 2013, was 76.8 thousand hectares, with a production of $109,473 \mathrm{Mg}$ and a seed yield of $1581.3 \mathrm{~kg} \mathrm{ha}^{-1}$ (FAO, 2016). Sunflower has diverse applications, therefore, its planted area in Brazil has been gradually expanding, generating new income and work opportunities to family agriculture because the use of cassava wastewater as soil fertilizer for this crop.

Studies on the reuse of cassava wastewater have been carried out by several researchers. Cabral et al. (2010) reported an increase in seed yield of black oats, evaluated under field conditions, reaching $3,795 \mathrm{~kg} \mathrm{ha}^{-1}$ on soil fertilized with $376 \mathrm{~m}^{3} \mathrm{ha}^{-1}$ of cassava wastewater. Duarte et al. (2012) used $45.0 \mathrm{~m}^{3} \mathrm{ha}^{-1}$ of cassava wastewater in substitution of soil mineral fertilizers for lettuce crops and found an increase in the phenotypic variables plant height, leaf number, total leaf area and shoot fresh and dry mass. Magalhães et al. (2014) evaluated maize grown on soil fertilized with cassava wastewater and found increases in culm diameter, number of leaves and leaf fresh and dry mass using a rate of $63 \mathrm{~m}^{3} \mathrm{ha}^{-1}$. Dantas et al. (2015) found increases in leaf number, leaf fresh and dry mass, stem and capitulum, in sunflower crops on soil fertilized with $136 \mathrm{~m}^{3} \mathrm{ha}^{-1}$ of cassava wastewater.

In this context, the objective of this work was to evaluate the growth and seed yield of sunflower on soil fertilized with cassava wastewater.

\section{MATERIAL AND METHODS}

The experiment was carried out in Vitória de Santo Antão, State of Pernambuco (PE), Brazil $\left(8^{\circ} 8^{\prime} 0^{\prime \prime} \mathrm{S}, 35^{\circ} 22^{\prime} 0^{\prime \prime} \mathrm{W}\right)$, from October 2012 to January 2013. The climate of the region is C1S2A A' a', according to the classification of Köppen. The soil of the experimental area was classified as Oxisol, whose physical (granulometry) and chemical characteristics (layer $0.0-0.40 \mathrm{~m}$ ) are presented in Table 1.

Table 1. Physical and chemical characteristics of the soil (layer $0.0-0.40 \mathrm{~m}$ ) of the experimental area, before the application of cassava wastewater.

\begin{tabular}{|c|c|c|c|c|c|c|c|c|c|c|c|c|}
\hline Sand & Silt & Clay & $\overline{\mathrm{pH}}$ & $\overline{\mathrm{EC}}$ & $\overline{\mathrm{P}}$ & $\mathrm{K}^{+}$ & $\mathrm{Ca}^{2+}$ & $\mathrm{Mg}^{2+}$ & $\mathrm{Na}^{+}$ & $\mathrm{Al}^{3+}$ & $\mathrm{H}^{+}+\mathrm{Al}^{3+}$ & $\overline{\mathrm{OC}}$ \\
\hline & $\mathrm{g} \mathrm{kg}^{-1}$ & & $1: 2.5 \mathrm{H}_{2} \mathrm{O}$ & $\mathrm{dS} \mathrm{m}^{-1}$ & $\mathrm{mg} \mathrm{dm}^{-3}$ & \multicolumn{6}{|c|}{$\mathrm{cmol}_{\mathrm{c}} \mathrm{dm}^{-3}$} & $\mathrm{~g} \mathrm{~kg}^{-1}$ \\
\hline 578 & 122 & 300 & 6.60 & 0.55 & 7.47 & 0.45 & 2.7 & 2.8 & 0.27 & 0.00 & 2.93 & 28 \\
\hline
\end{tabular}

$\mathrm{OC}=$ Organic Carbon; EC $=$ Electric Conductivity.

A randomized block experimental design with four replications was used, with six cassava wastewater rates $\left(0,8.5,17,34,68\right.$ and $\left.136 \mathrm{~m}^{3} \mathrm{ha}^{-1}\right)$, and six plant sampling times $(15,30,45,60,75$ and 90 days after sowing - DAS).

Each experimental plot consisted of four 6-m plant rows spaced $1.0 \mathrm{~m}$ apart with $0.20 \mathrm{~m}$ between plants, totaling 120 plants per plot, representing a density of 50,000 plants per hectare. The evaluation area of the plot $\left(10.4 \mathrm{~m}^{2}\right)$ consisted of the 52 central plants of the two central rows.

The physical and chemical composition of the cassava wastewater was determined using the APHA (1995) method, whose results of are presented in Table 2 . 
M. S. M. DANTAS et al.

Table 2. Physical and chemical characteristics of the cassava wastewater.

\begin{tabular}{|c|c|c|c|c|c|c|c|c|c|c|}
\hline COD & $\mathrm{EC}$ & $\mathrm{pH}$ & $\mathrm{N}$ & $\mathrm{P}$ & $\mathrm{K}^{+}$ & $\mathrm{Ca}^{2+}$ & $\mathrm{Mg}^{2+}$ & $\mathrm{Na}^{+}$ & $\mathrm{SO}^{2-}$ & $\mathrm{Cl}^{-}$ \\
\hline $\mathrm{mg} \mathrm{L}^{-1}$ & $\mathrm{dS} \mathrm{m}^{-1}$ & & \multicolumn{8}{|c|}{$\mathrm{mg} \mathrm{L}^{-1}$} \\
\hline 66.62 & 7.27 & 6.60 & $3,064.0$ & 312.0 & $3,200.0$ & 241.9 & $1,588.2$ & 390.0 & $2,205.0$ & 795.0 \\
\hline
\end{tabular}

$\mathrm{COD}=$ Chemical oxygen demand; $\mathrm{EC}=$ Electric Conductivity

The rate of cassava wastewater to be applied to the soil was calculated based on the potassium content found in this residue and the soil, since potassium is one of the most abundant elements in cassava wastewater. The potassium requirement for the sunflower crop was also considered, following the recommendation proposed by Ribeiro, Guimarães and Alvarez (1999) (25 kg ha ${ }^{-1}$ of potassium; $8.5 \mathrm{~m}^{3} \mathrm{ha}^{-1}$ of cassava wastewater) for the local conditions.

The other rates were calculated based on the recommended rate, considering multiples of it (2-, 4-, 8- and 16-fold the recommended rate). Mineral fertilizers and lime were not applied during the experiment, in order to evaluate only the effect of the cassava wastewater on the crop. The cassava wastewater rates were applied in a single application, at 15 days before sowing the sunflower seeds, so that the residue could be chemically balanced in the soil.

The soil preparation consisted of plowing, harrowing and furrowing, with row spacing of $1.0 \mathrm{~m}$ and depth of $0.3 \mathrm{~m}$. A drip irrigation system was used, with 16-mm flexible dripline, emitters spaced $0.2 \mathrm{~m}$ apart and flow of $1.0 \mathrm{~L} \mathrm{~h}^{-1}$. After the irrigation system was installed, 8-cm-deep furrows were dug, parallel to the plant rows, in which the cassava wastewater rates were applied as fertigation.

Seeds of the sunflower cultivar Helio-250 were sowed directly in the field, placing five seeds per hole. Seven days after the emergence the plants were thinned, leaving one plant per hole.

The irrigation water depth $(357 \mathrm{~mm})$ was determined based on the crop evapotranspiration (ETc), with reference evapotranspiration (ETo) estimated by the Hargreaves-Samani method, using the recommended crop coefficient (Kc) for sunflower, during the entire cycle.

Three sunflower plants from the evaluation area of each plot were sampled for growth analysis, with intervals of 15 days up to 90 days after sowing (DAS). The plants were cut near the ground level, fractionated in stems, leaves and inflorescences, packed in paper bags and placed in a forced air circulation oven at $65^{\circ} \mathrm{C}$ to a constant weight.

The total leaf area (TLA) was determined by the linear measures of leaf width proposed by Maldaner et al. (2009), estimated by the equation $T L A=1.7582 L^{1.7067}\left(R^{2}=0.983\right)$. Based on the TLA and dry masses of plants, the following characteristics were evaluated: leaf area index (LAI), calculated by the equation $L A I=T L A / S$, in which $T L A$ is the total leaf area and $S$ is the space available for the plant $(20 \times 100 \mathrm{~cm})$; leaf area ratio (LAR), calculated by the equation $L A R=T L A / T D M\left(\mathrm{~cm}^{2} \mathrm{~g}^{-1}\right)$, in which $T D M$ is the total dry mass; specific leaf area (SLA) calculated by the equation $S L A=T L A / L D M$ $\left(\mathrm{cm}^{2} \mathrm{~g}^{-1}\right)$, in which $L D M$ is the leaf dry mass; and leaf weight ratio: $L W R=L D M / T D M \quad$ (g) (BENINCASA, 2003).

The Mauchly's sphericity test was applied to define the type of statistical analysis to be used on the data, univariate (with independence of the measures over time) or multivariate (without independence of the measures over time). The results of the Mauchly's test $(p<0.01)$ indicated the use of the multivariate analysis through repeated measurements over time. The variables that presented significant responses were then subjected to regression analysis, using mathematical models with the highest coefficient of determination at $5 \%$ of significance.

\section{RESULTS AND DISCUSSIONS}

According to the results of the analysis of variance, the plant sampling times (PST) and cassava wastewater rates (CWR) had significant effects on the total leaf area (TLA), leaf area index (LAI), leaf area ratio (LAR), specific leaf area (SLA) and leaf weight ratio (LWR) (Table 3). Thus, these results were subjected to test of means to verify the PST $\mathrm{x}$ CWR interaction.

Table 3. Analysis of variance of the total leaf area (TLA), leaf area index (LAI), leaf area ratio (LAR), specific leaf area (SLA) and leaf weight ratio (LWR) of sunflower on soil fertilized with cassava wastewater.

\begin{tabular}{|c|c|c|c|c|c|c|}
\hline \multirow{2}{*}{ Source of Variation } & \multirow{2}{*}{$\mathrm{DF}$} & \multicolumn{5}{|c|}{$\operatorname{Pr}>F$} \\
\hline & & TLA & LAI & LAR & SLA & LWR \\
\hline Time & 5 & $<0.0001$ & $<0.0001$ & $<0.0001$ & $<0.0001$ & $<0.0001$ \\
\hline Time $x$ Rate & 25 & $<0.0001$ & $<0.0001$ & $<0.0001$ & $<0.0001$ & 0.0401 \\
\hline Residue & 75 & & & & & \\
\hline
\end{tabular}

$\mathrm{DF}=$ Degrees of freedom; $\operatorname{Pr}>\mathrm{F}=$ Significance level. 
The interaction between PST and CWR was significant for all variables evaluated. The results of the sunflower total leaf area (TLA) presented a quadratic response to the cassava wastewater rates over time (Figure 1A).

The maximum TLA found were $2,131.85 \mathrm{~cm}^{2}$ (rate of 0 , at 71 days after sowing DAS) $2,571.82 \mathrm{~cm}^{2}$ (rate of $8.5 \mathrm{~m}^{3} \mathrm{ha}^{-1}$, at $68 \mathrm{DAS}$ ), $2,815.29 \mathrm{~cm}^{2}$ (rate of $17 \mathrm{~m}^{3} \mathrm{ha}^{-1}$, at $66 \mathrm{DAS}$ ), $3,631.71 \mathrm{~cm}^{2}$ (rate of $34 \mathrm{~m}^{3} \mathrm{ha}^{-1}, 66 \mathrm{DAS}$ ), 4,536.02 $\mathrm{cm}^{2}$ (rate of $68 \mathrm{~m}^{3} \mathrm{ha}^{-1}$ and 63 DAS),

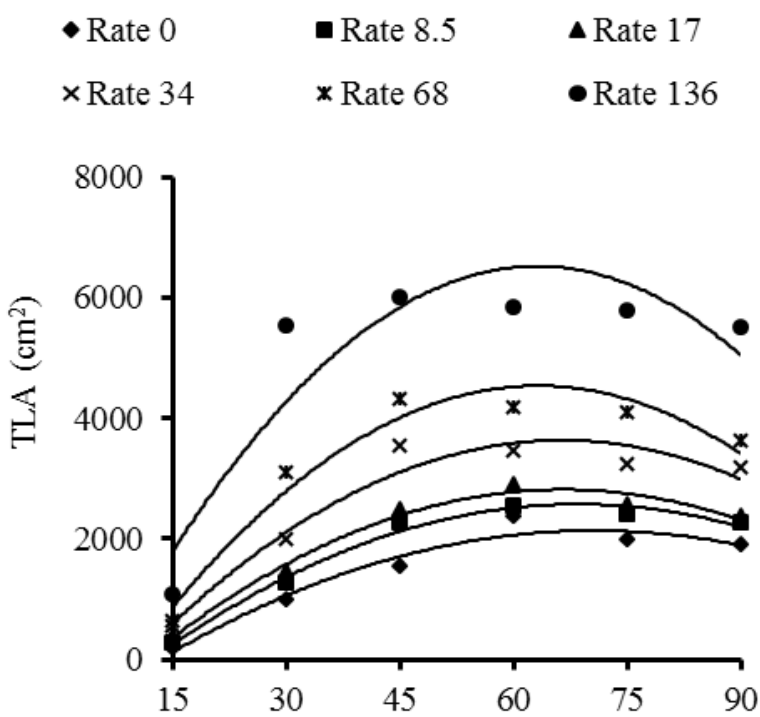

A

Days after emergence

Rate $0 \hat{\mathrm{Y}}=-0.653^{* *} \mathrm{x}^{2}+92.159^{* *} \mathrm{x}-1120.11 \quad \mathrm{R}^{2}=0.95$ Rate $8.5 \hat{\mathrm{Y}}=-0.820^{* *} \mathrm{x}^{2}+112.239^{*} \mathrm{x}-1268.30 \quad \mathrm{R}^{2}=0.99$ Rate $17 \hat{Y}=-0.929^{* *} x^{2}+123.487^{* *} \mathrm{x}-1290.05 \quad R^{2}=0.98$ Rate $34 \hat{\mathrm{Y}}=-1.155^{* *} \mathrm{x}^{2}+153.278^{* *} \mathrm{x}-1451.76 \quad \mathrm{R}^{2}=0.95$ Rate $68 \hat{\mathrm{Y}}=-1.584^{* *} \mathrm{x}^{2}+200.166^{* *} \mathrm{x}-1787.89 \quad \mathrm{R}^{2}=0.95$ Rate $136 \hat{\mathrm{Y}}=-2.049^{* *} \mathrm{x}^{2}+258.360^{* *} \mathrm{x}-1632.44 \mathrm{R}^{2}=0.84$
$6,512.72 \mathrm{~cm}^{2}$ (rate of $136 \mathrm{~m}^{3} \mathrm{ha}^{-1}, 63 \mathrm{DAS}$ ). These results showed that the higher rates accelerated the development stages of the culture. The vegetative stages, and especially the reproductive stage, are favored by the carbon/nitrogen balance $(\mathrm{C} / \mathrm{N})$, which is quantitatively favorable to the first assimilated compounds (TAIZ; ZEIGER, 2013), and since the cassava wastewater is a residue that supplies carbon and nitrogen, the acceleration of the development stages, which were eight days early, may be related to the adequate supply of these two nutrients.

$\begin{array}{lll}\bullet \text { Rate } 0 & \boldsymbol{\Delta} \text { Rate } 8.5 & \boldsymbol{\Delta} \text { Rate } 17 \\ \times \text { Rate } 34 & \text { * Rate 68 } & \bullet \text { Rate 136 }\end{array}$

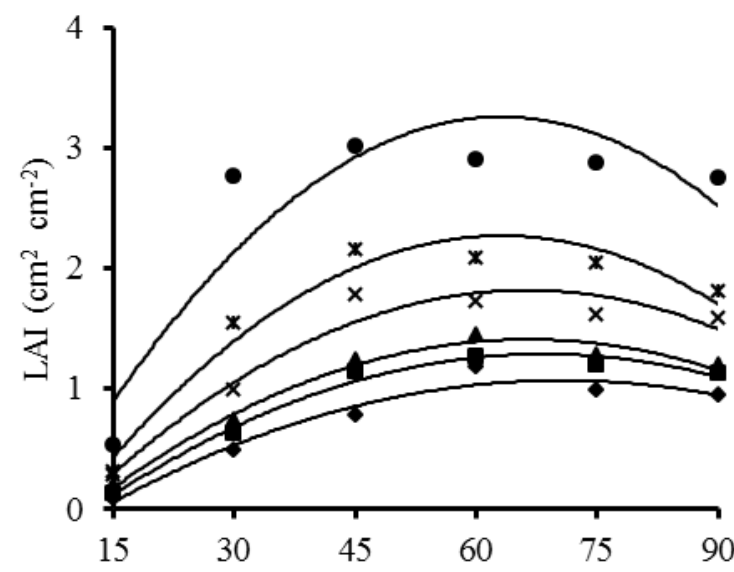

$\mathrm{B}$

Days after emergence

Rate $0 \hat{\mathrm{Y}}=-0.000326^{* *} \mathrm{x}^{2}+0.0461^{* *} \mathrm{x}-0.560 \quad \mathrm{R}^{2}=0.95$

Rate $8.5 \hat{Y}=-0.000410^{* *} x^{2}+0.056^{* *} \mathrm{x}-0.634 \quad \mathrm{R}^{2}=0.90$

Rate $17 \hat{\mathrm{Y}}=-0.000464^{* *} \mathrm{x}^{2}+0.062^{* *} \mathrm{x}-0.645 \quad \mathrm{R}^{2}=0.98$

Rate $34 \hat{\mathrm{Y}}=-0.000578 \mathrm{x}^{* * 2}+0.077^{* *} \mathrm{x}-0.726 \quad \mathrm{R}^{2}=0.95$

Rate $68 \hat{\mathrm{Y}}=-0.000792^{* *} \mathrm{x}^{2}+0.100^{* *} \mathrm{x}-0.894 \quad \mathrm{R}^{2}=0.95$

Rate $136 \hat{\mathrm{Y}}=-0.001100^{* *} \mathrm{x}^{2}+0.129^{* *} \mathrm{x}-0.811 \quad \mathrm{R}^{2}=0.84$

Figure 1. Total leaf area (TLA) (A) and leaf area index (LAI) (B) of sunflower on soil fertilized with different rates of cassava wastewater, in different evaluation times.

The maximum TLA was reached around 66 DAS for all rates, and then this variable decreased throughout the evaluation time (Figure 1A). This result was due to abscission and natural senescence of leaves, which occur by the end of the crop cycle, because the targeting of photoassimilates is preferential to the fruits during this stage (TAIZ; ZEIGER, 2013)

The results of TLA confirm those found by Aquino, Silva and Berger (2013) in sunflower plants (cultivars BR-122 and M-74) under field conditions, in Januária, State of Minas Gerais, Brasil. They found, by a non-destructive method, an average TLA of $6,278 \mathrm{~cm}^{2}$ plant ${ }^{-1}$ by the end of the flowering stage. Duarte et al. (2012) also found an increase of TLA in lettuce, grown in greenhouse, with quadratic response to the application of the cassava wastewater rates $\left(0,12.5,25.0,45.0\right.$ and $\left.65.0 \mathrm{~m}^{3} \mathrm{ha}^{-1}\right)$, from which the application rate of $45 \mathrm{~m}^{3} \mathrm{ha}^{-1}$ resulted in the largest TLA.

The results of the sunflower leaf area index (LAI) also presented a quadratic response to the cassava wastewater rates over time (Figure 1B). The maximum LAI found were $1.07\left(0 \mathrm{~m}^{3} \mathrm{ha}^{-1}\right), 1.29$ (8.5 $\left.\mathrm{m}^{3} \mathrm{ha}^{-1}\right), 1.65\left(17 \mathrm{~m}^{3} \mathrm{ha}^{-1}\right), 1.81\left(34 \mathrm{~m}^{3} \mathrm{ha}^{-1}\right)$, $2.27\left(68 \mathrm{~m}^{3} \mathrm{ha}^{-1}\right)$ and $2.97 \mathrm{~cm}^{2} \mathrm{~cm}^{-2}\left(136 \mathrm{~m}^{3} \mathrm{ha}^{-1}\right)$ at 65 DAS, then, the LAI decreased, presenting 0.95 $\left(0 \mathrm{~m}^{3} \mathrm{ha}^{-1}\right), 1.08\left(8.5 \mathrm{~m}^{3} \mathrm{ha}^{-1}\right), 1.15\left(17 \mathrm{~m}^{3} \mathrm{ha}^{-1}\right), 1.49$ $\left(34 \mathrm{~m}^{3} \mathrm{ha}^{-1}\right), 1.70\left(68 \mathrm{~m}^{3} \mathrm{ha}^{-1}\right)$ and $2.52 \mathrm{~cm}^{2} \mathrm{~cm}^{-2}$ $\left(136 \mathrm{~m}^{3} \mathrm{ha}^{-1}\right)$ at 90 DAS.

According to Benincasa (2003), the leaf area index is the relation between leaf area and soil area shaded by leaves. Thus, the LAI increases with increasing leaf area until the self-shading becomes harmful, decreasing the photosynthetic efficiency of the plant. In general, LAI from 2.5 to $3 \mathrm{~cm}^{2} \mathrm{~cm}^{-2}$ at 
full flowering is ideal to high seed yields in sunflower crops (BRAZ; ROSSETTO, 2009). Thus, a cassava wastewater rate of $136 \mathrm{~m}^{3} \mathrm{ha}^{-1}$ can promote high seed yields, since a LAI of 2.97 was found at full flowering (58 DAS) with this rate.

The leaf area ratio (LAR) expresses the photosynthetic leaf area, i.e., the relation between the leaf area that intercept light energy and $\mathrm{CO}_{2}$ and the total dry mass resulting from photosynthesis. The interference of the upper on the lower leaves increases with the plant growth, reducing the photosynthetic leaf area (BENINCASA, 2003).
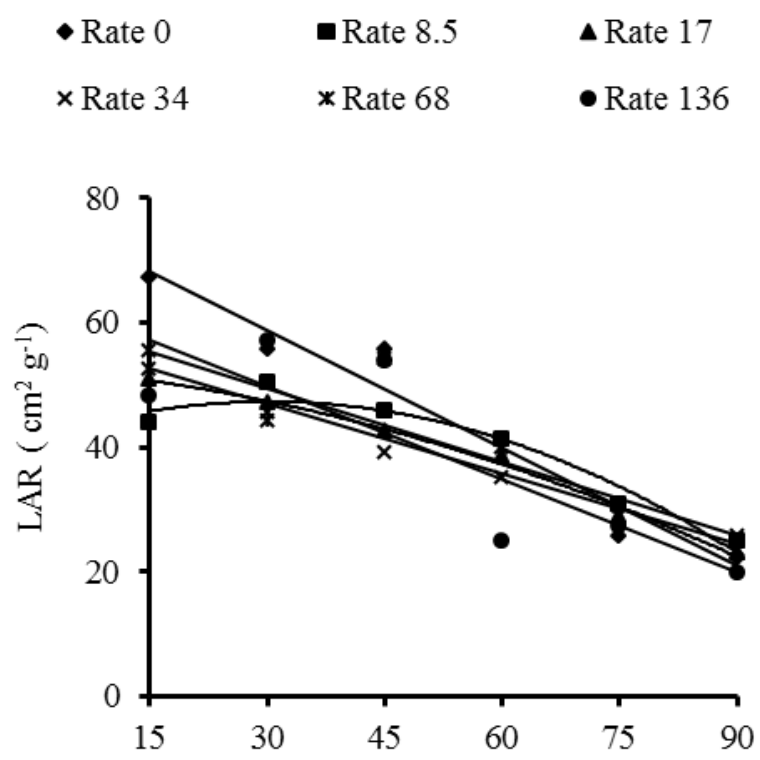

A

Days after emergence

Rate $0 \hat{\mathrm{Y}}=77.534-0.628^{* *} \mathrm{x} \quad \mathrm{R}^{2}=0.95$

Rate $8.5 \hat{\mathrm{Y}}=55.354-0.303^{* *} \mathrm{x} \quad \mathrm{R}^{2}=0.76$

Rate $17 \hat{\mathrm{Y}}=58.282-0.377^{* *} \times \mathrm{R}^{2}=0.97$

Rate $34 \hat{\mathrm{Y}}=58.296-0.377^{* *} \mathrm{x} \quad \mathrm{R}^{2}=0.97$

Rate $68 \hat{\mathrm{Y}}=61.023-0.391^{* *} \times \mathrm{R}^{2}=0.79$

Rate $136 \hat{\mathrm{Y}}=64.56-0.497^{* *} \times \mathrm{R}^{2}=0.73$
The results of the sunflower leaf area ratio (LAR) presented a negative linear response to the cassava wastewater rates over time. LAR of 68.12 $\left(0 \mathrm{~m}^{3} \mathrm{ha}^{-1}\right), 50.81\left(8.5 \mathrm{~m}^{3} \mathrm{ha}^{-1}\right), 52.63\left(17 \mathrm{~m}^{3} \mathrm{ha}^{-1}\right)$, $52.64\left(34 \mathrm{~m}^{3} \mathrm{ha}^{-1}\right), \quad 55.16 \quad\left(68 \mathrm{~m}^{3} \mathrm{ha}^{-1}\right)$ and $57.11 \mathrm{~cm}^{2} \mathrm{~g}^{-1}\left(136 \mathrm{~m}^{3} \mathrm{ha}^{-1}\right)$ were found at $15 \mathrm{DAS}$, which decreased to $21.06\left(0 \mathrm{~m}^{3} \mathrm{ha}^{-1}\right), 28.08$ $\left(8.5 \mathrm{~m}^{3} \mathrm{ha}^{-1}\right), 24.35\left(17 \mathrm{~m}^{3} \mathrm{ha}^{-1}\right), 24.37\left(34 \mathrm{~m}^{3} \mathrm{ha}^{-1}\right)$, $25.82\left(68 \mathrm{~m}^{3} \mathrm{ha}^{-1}\right)$ and $19.83 \mathrm{~cm}^{2} \mathrm{~g}^{-1}\left(136 \mathrm{~m}^{3} \mathrm{ha}^{-1}\right)$ at 90 DAS (Figure 2A). Thus, the photosynthetic leaf area of the plants decreased as a function of plant age and accumulation of dry mass by the plants.
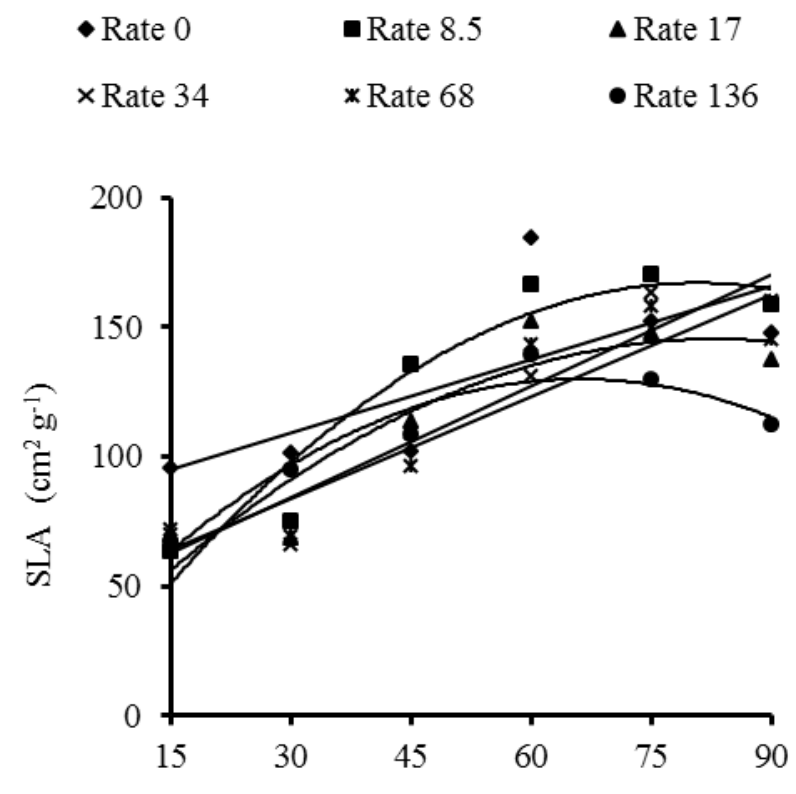

B Days after emergence

Rate $0 \hat{\mathrm{Y}}=50.13+2.470 \mathrm{x}-0.015^{* *} \mathrm{x}^{2} \mathrm{R}^{2}=0.60$

Rate $8.5 \hat{Y}=7.603+4.326 x-0.027^{* *} x^{2} R^{2}=0.92$

Rate $17 \hat{\mathrm{Y}}=12.642+3.197 \mathrm{x}-0.019^{* *} \mathrm{x}^{2} \mathrm{R}^{2}=0.85$

Rate $34 \hat{\mathrm{Y}}=18.97+3.362 \mathrm{x}-0.026^{* *} \mathrm{x}^{2} \mathrm{R}^{2}=0.93$

Rate $68 \hat{\mathrm{Y}}=25.94+2.237 \mathrm{x}-0.009^{* *} \mathrm{x}^{2} \mathrm{R}^{2}=0.87$

Rate $136 \hat{\mathrm{Y}}=18.97+3.362 \mathrm{x}-0.026^{* *} \mathrm{x}^{2} \mathrm{R}^{2}=0.93$

Figure 2. Leaf area ratio (LAR) and specific leaf area (SLA) of sunflower grown on soil fertilized with different rates of cassava wastewater, in different evaluation times.

These results confirm those found by Lopes et al. (2011), who found a decrease in leaf area ratio in tomato crops, as a function of plant age. The decrease of the LAR throughout the crop cycle is related to the reduction of photoassimilates to the older organs, which causes a reduction in the relative growth rate of the plants. Silva et al. (2010) evaluated the growth of sweet pepper at different spacing between plants and found similar responses.

According to Fontes, Dias and Silva (2005), the specific leaf area (SLA) is the photosynthetic area per dry mass of leaf, and the inverse of the specific leaf area indicates the leaf thickness. The results of the sunflower SLA presented a quadratic response to the cassava wastewater rates over time (Figure 2B), with maximum SLA of 167 $\left(8.5 \mathrm{~m}^{3} \mathrm{ha}^{-1}, 81\right.$ DAS $), 145\left(17 \mathrm{~m}^{3} \mathrm{ha}^{-1}, 83\right.$ DAS $)$ and $129.76 \mathrm{~cm}^{2} \mathrm{~g}^{-1}\left(136 \mathrm{~m}^{3} \mathrm{ha}^{-1}, 66\right.$ DAS). The SLA had small decrease, denoting the increase of leaf dry mass, however, the plants continued to expand their leaf area.

The leaf weight ratio (LWR) is the dry mass produced by photosynthesis that is not used for respiration nor exported to other parts of the plant, representing the plant production of leaves, via photosynthesis (BENINCASA, 2003). The LWR was similar in all treatments, with negative linear responses from 15 to 90 DAS (Figure 3). 


$\begin{array}{lll}\bullet \text { Rate } 0 & \boldsymbol{\square} \text { Rate } 8.5 & \boldsymbol{\Delta} \text { Rate } 17 \\ \mathbf{x} \text { Rate } 34 & \boldsymbol{*} \text { Rate } 68 & \bullet \text { Rate } 136\end{array}$

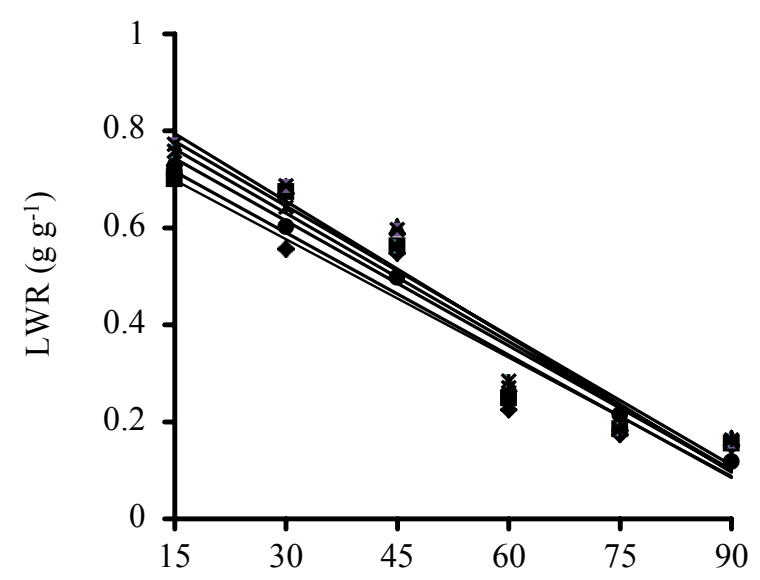

A

$$
\begin{aligned}
& \text { Rate } 0 \hat{\mathrm{Y}}=0.820-0.008^{* *} \mathrm{x} \\
& \text { Rate } 8.5 \hat{\mathrm{Y}}=0.871-0.009^{* *} \mathrm{x} \\
& \text { Rate } 17 \hat{\mathrm{Y}}=0.912-0.009^{* *} \mathrm{X} \\
& \text { Rate } 34 \hat{\mathrm{Y}}=0.912-0.009^{* *} \mathrm{x} \\
& \text { Rate } 68 \hat{\mathrm{Y}}=0.895-0.009^{* *} \mathrm{x} \\
& \text { Rate } 136 \hat{\mathrm{Y}}=0.842-0.008^{* *} \mathrm{x}
\end{aligned}
$$

Days after emergence

$$
\begin{aligned}
& \mathrm{R}^{2}=0.91 \\
& \mathrm{R}^{2}=0.92 \\
& \mathrm{R}^{2}=0.92 \\
& \mathrm{R}^{2}=0.93 \\
& \mathrm{R}^{2}=0.95 \\
& \mathrm{R}^{2}=0.97
\end{aligned}
$$
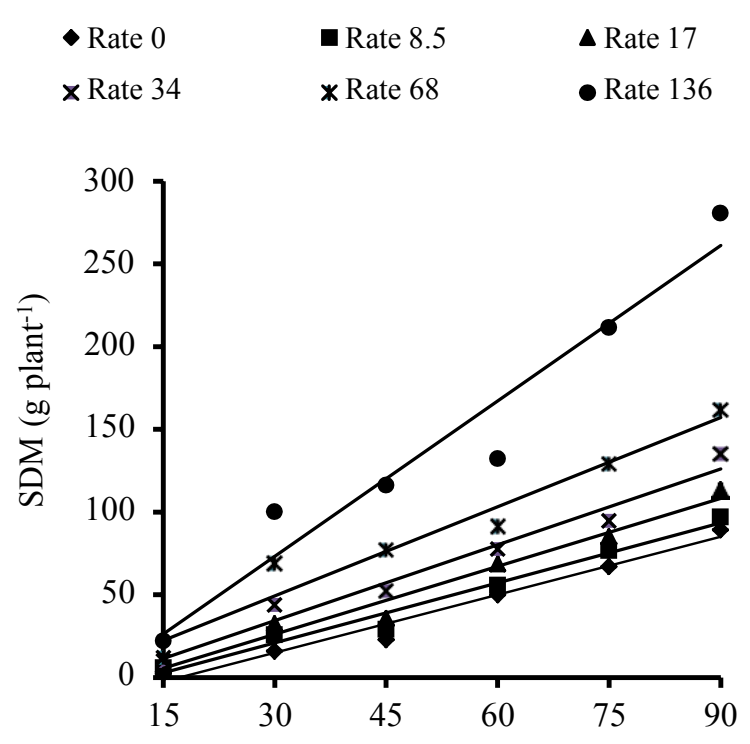

B

$$
\begin{array}{ll}
\text { Rate } 0 \hat{\mathrm{Y}}=-20.093+1.169^{* *} \mathrm{x} & \mathrm{R}^{2}=0.97 \\
\text { Rate } 8.5 \hat{\mathrm{Y}}=-15.06+1.207^{* *} \mathrm{x} & \mathrm{R}^{2}=0.97 \\
\text { Rate } 17 \hat{\mathrm{Y}}=-14.74+1.368^{* *} \mathrm{x} & \mathrm{R}^{2}=0.97 \\
\text { Rate } 34 \hat{\mathrm{Y}}=-11.48+1.530^{* *} \mathrm{x} & \mathrm{R}^{2}=0.97 \\
\text { Rate } 68 \hat{\mathrm{Y}}=-4.37+1.796^{* *} \mathrm{x} & \mathrm{R}^{2}=0.95 \\
\text { Rate } 136 \hat{\mathrm{Y}}=-20.47+3.128^{* *} \mathrm{x} & \mathrm{R}^{2}=0.94
\end{array}
$$

Figure 3. Leaf weight ratio (LWR) and shoot dry mass (SDM) of sunflower grown under different rates of cassava wastewater, in different evaluation times.

The leaf weight ratios (LWR) estimated by regression equations were $0.699\left(0 \mathrm{~m}^{3} \mathrm{ha}^{-1}\right), 0.742$ $\left(8.5 \mathrm{~m}^{3} \mathrm{ha}^{-1}\right), 0.778\left(17 \mathrm{~m}^{3} \mathrm{ha}^{-1}\right), 0.778\left(34 \mathrm{~m}^{3} \mathrm{ha}^{-1}\right)$, $0.763\left(68 \mathrm{~m}^{3} \mathrm{ha}^{-1}\right)$, and $0.716 \mathrm{~g} \mathrm{~g}^{-1}\left(136 \mathrm{~m}^{3} \mathrm{ha}^{-1}\right)$ at 15 DAS, which decreased to $0.091\left(0 \mathrm{~m}^{3} \mathrm{ha}^{-1}\right), 0.097$ $\left(8.5 \mathrm{~m}^{3} \mathrm{ha}^{-1}\right), 0.111\left(17 \mathrm{~m}^{3} \mathrm{ha}^{-1}\right), 0.111\left(34 \mathrm{~m}^{3} \mathrm{ha}^{-1}\right)$, $0.102\left(68 \mathrm{~m}^{3} \mathrm{ha}^{-1}\right)$ and $0.069 \mathrm{~g} \mathrm{~g}^{-1}\left(136 \mathrm{~m}^{3} \mathrm{ha}^{-1}\right)$ at 90 DAS, showing a mean decrease of $87 \%$. This decrease was expected due to the decrease of the leaf weight ratio in the total dry mass composition, due to the formation of new organs, such as branches and capitula.

Oliveira, Pereira and Gomide (2000) also found a negative linear response of LWR over time in the grass Tifton-85, with maximum and minimum LWR of 0.59 and $0.27 \mathrm{~g} \mathrm{~g}^{-1}$ at 14 and 70 days of regrowth, respectively. Rodrigues et al. (2008) evaluated the grass Brachiaria brizantha cv. Xaraés, grown under different nitrogen and potassium rates and found a decrease in LWR with increasing nitrogen rates, however, the LWR was not affected by the potassium rates.

The shoot dry mass (SDM) was similar in all treatments, with increased SDM with increasing cassava wastewater rates (Figure 3B). SDM of 0.82 $\left(0 \mathrm{~m}^{3} \mathrm{ha}^{-1}\right), 3.05\left(8.5 \mathrm{~m}^{3} \mathrm{ha}^{-1}\right), 5.79\left(17 \mathrm{~m}^{3} \mathrm{ha}^{-1}\right)$, $11.50 \quad\left(34 \mathrm{~m}^{3} \mathrm{ha}^{-1}\right), 22.57 \quad\left(68 \mathrm{~m}^{3} \mathrm{ha}^{-1}\right)$ and $26.46 \mathrm{~g} \mathrm{plant}^{-1}\left(136 \mathrm{~m}^{3} \mathrm{ha}^{-1}\right)$ were found at $15 \mathrm{DAS}$, which increased to $88.12\left(0 \mathrm{~m}^{3} \mathrm{ha}^{-1}\right), 93.58$
(8.5 $\left.\mathrm{m}^{3} \quad \mathrm{ha}^{-1}\right), \quad 108.39 \quad\left(17 \mathrm{~m}^{3} \quad \mathrm{ha}^{-1}\right), \quad 126.32$ $\left(34 \mathrm{~m}^{3} \mathrm{ha}^{-1}\right), 157.27\left(68 \mathrm{~m}^{3} \mathrm{ha}^{-1}\right)$ and $261.06 \mathrm{~g} \mathrm{plant}^{-1}$ $\left(136 \mathrm{~m}^{3} \mathrm{ha}^{-1}\right)$ at 90 DAS.

The maximum SDM was found in the treatment with the highest rate of cassava wastewater, denoting the efficient use of the nutrients present in this residue by the plants (Figure 3B). The SDM results confirm those found by Zobiole et al. (2010), who evaluated the nutrient uptake rate of sunflower (variety BRS-19) grown in a eutrophic Red Latosol and found maximum dry mass index of $272.75 \mathrm{~g} \mathrm{plant}^{-1}$ at 89 DAS.

Experiments conducted on other crops also show increases of SDM with the use of cassava wastewater as a source of nutrients. Cabral et al. (2010) evaluated black oats (Avena strigosa) grown in the field and found a quadratic response of the SDM to the cassava wastewater rates, with a rate of $376 \mathrm{~m}^{3} \mathrm{ha}^{-1}$ presenting the highest SDM (212 g plant $^{-1}$ ), which was attributed mainly to the high content of potassium and nitrogen in the residue.

Duarte et al. (2012) found quadratic response of SDM to the application of different cassava wastewater rates $(0,12.5,25.0,45.0$ and $65.0 \mathrm{~m}^{3} \mathrm{ha}^{-1}$ ) for soil fertilization in lettuce crops, with the maximum SDM (estimated by regression) of $4.86 \mathrm{~g}$ plants $^{-1}$ in treatments with rate of $45 \mathrm{~m}^{3} \mathrm{ha}^{-1}$. 
The results of the sunflower seed yield (SSY) presented a positive linear response to the cassava wastewater rates over time, with estimated SSY of $2,476.3\left(0 \quad \mathrm{~m}^{3} \mathrm{ha}^{-1}\right)$ and 4,553.56 $\mathrm{kg} \mathrm{ha}^{-1}$ $\left(136 \mathrm{~m}^{3} \mathrm{ha}^{-1}\right)$, denoting an increase of $83.9 \%$ (Figure 4A).
Uchôa et al. (2011) evaluated three sunflower varieties and five potassium rates (topdressing) $(0$, $30,60,90$ and $120 \mathrm{~kg} \mathrm{ha}^{-1}$ ) and found increased seed yield with increasing $\mathrm{K}$ rates, reaching $2,038.3 \mathrm{~kg} \mathrm{ha}^{-1}$ of sunflower seeds.

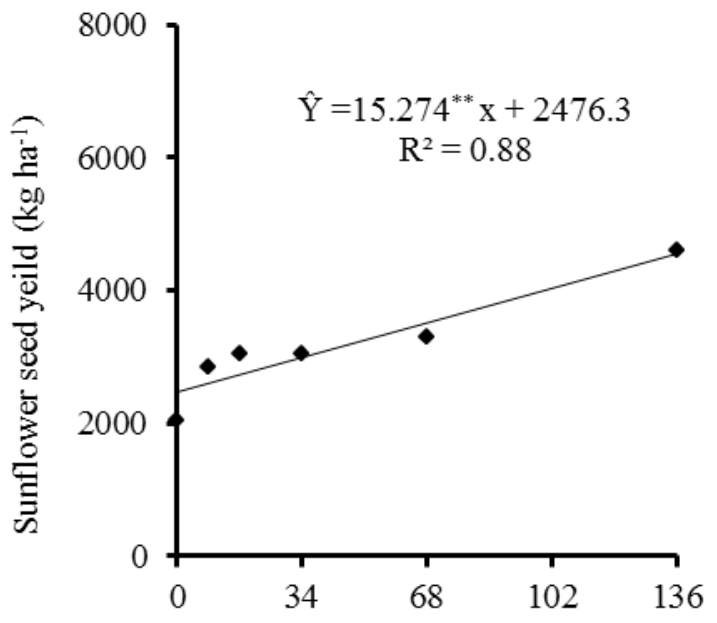

Cassava wastewater rates $\mathrm{m}^{3} \mathrm{ha}^{-1}$

Figure 4. Seed yield of sunflower plants grown on soil fertilized with different rates of cassava wastewater.

\section{CONCLUSIONS}

The use of cassava wastewater as soil fertilizer improves the development of sunflower (cv. Helio-250) crops.

The rate of $136 \mathrm{~m}^{3} \mathrm{ha}^{-1}$ of cassava wastewater increases the seed yield, leaf area, leaf area index and shoot dry mass, and results in lower leaf area ratio, specific leaf area and leaf weight ratio of sunflower (cv. Helio-250) crops.

The use of $136 \mathrm{~m}^{3} \mathrm{ha}^{-1}$ of cassava wastewater as soil fertilizer is recommended for sunflower (cv. Helio-250) crops.

\section{REFERENCES}

\section{AMERICAN PUBLIC HEALTH ASSOCIATION - APHA, AMERICAN WATER WORKS ASSOCIATION - AWWA, WASHINGTON PRESS CLUB FOUNDATION - WPCF. Standard methods for the examination of water and wastewater. Washington: American Public Halth Association, 17. ed. 1995.2198 p.}

AQUINO, L. A.; SILVA, F. D. B.; BERGER, P. G. Características agronômicas e o estado nutricional de cultivares de girassol irrigado. Revista Brasileira de Engenharia Agrícola e Ambiental, Campina Grande, v. 17, n. 5, p. 551-557, 2013.

BENINCASA, M. M. P. Análise de crescimento de plantas: noções básicas. 2. ed. Jaboticabal, SP: FUNEP, 2003. 41 p.

BRAZ, M. R. S.; ROSSETTO, C. A. V. Crescimento de plantas de girassol em função do vigor de aquênios e da densidade de semeadura. Ciência Rural, Santa Maria, v. 39, n. 7, p. 1989-1996, 2009.

CABRAL, J. R. et al. Effects of wastewater from a cassava industry on soil chemistry and crop yield of lopsided oats (Avena strigosa Schreb). Brazilian Archives of Biology \& Technology, Curitiba, v. 53, n. 1, p. 19-26. 2010.

CAMPOS, A. T. et al. Tratamento de águas residuárias de fecularia por meio de lagoas de estabilização. Engenharia Agrícola, Jaboticabal, v. 26, n. 1, p. 235-242, 2006.

CARDOSO, E. et al. Use of Manihot esculenta, crantz processing residue as biofertilizer in corn crops. Research Journal of Agronomy, Criciúma, v. 3, n. 1, p. 1-8, 2009.

DANTAS, M. S. M. et al. Crescimento do girassol adubado com resíduo líquido do processamento de mandioca. Revista Brasileira de Engenharia Agrícola e Ambiental, Campina Grande, v. 19, n. 4, p. $350-357,2015$.

DUARTE, A. S. et al. Uso de diferentes rates de manipueira na cultura da alface em substituição à adubação mineral. Revista Brasileira de 
Engenharia Agrícola e Ambiental, Campina Grande, v. 16, n. 3, p. 262-267, 2012.

FONTES, P. C. R.; DIAS, E. N.; SILVA, D. J. H. Dinâmica do crescimento, distribuição de matéria seca na planta e produção de pimentão em ambiente protegido. Horticultura Brasileira, Brasília, v. 23, n. 1, p. 94-99, 2005.

FOOD AND AGRICULTURE ORGANIZATION FAO. Anuários Estatísticos da FAO. Disponível em: <http://www.faostat.fao.org/>. Acesso em 08 mar. 2016.

LOPES, W. A. R. et al. Análise do crescimento de tomate 'SM-16' cultivado sob diferentes coberturas de solo. Horticultura Brasileira, Brasília, v. 29, n. 4, p. 554-561, 2011.

MAGALHÃES, A. G. et al. Desenvolvimento inicial do milho submetido à adubação com manipueira. Revista Brasileira de Engenharia Agrícola e Ambiental, Campina Grande, v. 18, n. 7, p. 675-681, 2014.

MALDANER, I. C. et al. Modelos de determinação não-destrutiva da área foliar em girassol. Ciência Rural, Santa Maria, v. 39, n. 3, p. 1356-1361, 2009.

OLIVEIRA, M. A.; PEREIRA, O. G.; GOMIDE, J. A. Análise de crescimento do capim-bermuda "Tifton 85" (Cynodon spp.). Revista Brasileira de Zootecnia, Viçosa, v. 29, n. 6, p. 1930-1938, 2000.

RIBEIRO, A. C.; GUIMARÃES, P. T. G.; ALVAREZ, V. V. H. Recomendação para o uso de corretivos e fertilizantes em Minas Gerais. $5^{\text {a }}$ aproximação. Viçosa, MG: Comissão de Fertilidade do Solo do Estado de Minas Gerais, 1999. 359 p.

RODRIGUES, R. C. et al. Produção de massa seca, relação folha/colmo e alguns índices de crescimento do Brachiaria brizantha cv. Xaraés cultivado com a combinação de rates de nitrogênio e potássio. Revista Brasileira de Zootecnia, Viçosa, v. 37, n. 3, p. 394-400, 2008.

SILVA, P. I. B. et al. Crescimento de pimentão em diferentes arranjos espaciais. Pesquisa Agropecuária Brasileira, Brasília, v. 45, n. 2, p. 132-139. 2010.

TAIZ, L.; ZEIGER, E. Fisiologia vegetal. 5. ed. Porto Alegre, RS: Artmed, 2013. 820 p.

UCHÔA, S. C. P. et al. Adubação de potássio em cobertura nos componentes de produção em cultivares de girassol. Revista Ciência Agronômica, Fortaleza, v. 41, n. 1, p. 8-15, 2011.
ZOBIOLE, L. H. S. et al. Marcha de absorção de macronutrientes na cultura do girassol. Revista Brasileira de Ciência do Solo, Viçosa, v. 34, n. 2, p. 425-433, 2010. 